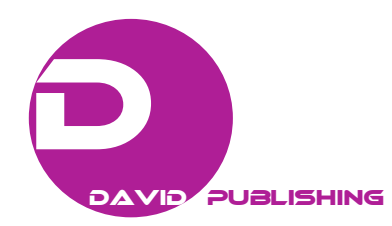

\title{
Environmental and Social Impacts of Mini-hydropower Plants-A Case Study from Sri Lanka
}

\author{
Prasad G. Senarath ${ }^{1}$, Bhabishya Khaniya ${ }^{1}$, Nilushi Baduge ${ }^{2}$, Hazi Md. Azamathulla ${ }^{3}$ and Upaka Rathnayake ${ }^{1,4}$ \\ 1. Department of Civil Engineering, Faculty of Engineering, Sri Lanka Institute of Information Technology, Malabe 10115, Sri \\ Lanka; \\ 2. Country Energy (Pvt) Ltd, World Trade Center, Colombo 00100, Sri Lanka; \\ 3. Sensor Networks and Cellular Systems (SNCS) Research Center, University of Tabuk, Tabuk 47713, Saudi Arabia; \\ 4. 21 Huth Street, Labrador, 4215, Queensland, Australia
}

\begin{abstract}
This research study was conducted to review the environmental and social impact of mini hydropower plants (run-of-the-river type) by selecting Denawaka Ganga mini hydropower plant, which is located in Ratnapura district, Sri Lanka. Field visits and discussions among the authors, authorities and the residents were carried out. Then, the environmental and social impacts were scientifically analysed using regulation degree $(R D)$ and environmental impact value $(E I V)$ scores. It was found out that the Denawaka Ganga mini hydropower plant has induced some environmental concerns; however, significant positive social impact to the society. This is in addition to the green energy generation. Therefore, it can be concluded herein that the Denawaka Ganga mini hydropower is an asset to the country, Sri Lanka.
\end{abstract}

Key words: Denawaka Ganga hydropower plant, environmental impact value, mini hydropower plants, regulation degree, social impacts.

\section{Introduction}

Hydropower plays an important part of the electricity production in world including Sri Lanka. The total hydropower potential in Norway is $159 \mathrm{TWh}$ per year according to the Norwegian Water Resources and Energy Directorate [1]. Out of this 159 TWh, the annual generation lies around $120 \mathrm{TWh}$. On the other hand, China expected $194 \mathrm{GW}$ from hydropower in 2010 to support their fast-growing economy [2]. In addition, India is none second to any of the countries in development of hydropower [3]. The usage is popular among many countries because hydropower brings many advantages to the economy and the society of the countries. It is one of the most reliable renewable energy sources to develop the electricity to date in the world [4-6]. In addition, it may be one of the cheapest

Corresponding author: Upaka Rathnayake, Ph.D.; research field: wather resources management. E-mail: upakasanjeewa@yahoo.com. renewable energy resources to develop electricity [7-10]. Therefore, many countries look for the potential of hydropower by researching new locations to hydropower development [11-16].

Hydropower projects can be classified into several clusters depending on the generated power. There is no standard or clear cutting rule for the classification [17]; however, it is based on the practice. According to Williams and Porter [18], a large hydropower project produces more than $100 \mathrm{MW}$. In between 10-100 MW, 1-10 MW, $100 \mathrm{~kW}-1 \mathrm{MW}$ are called medium, small and mini, respectively. The classification further goes to the smaller levels. In between $5-100 \mathrm{~kW}$ are called micro hydropower projects whereas pico hydropower projects if the generated capacity is less than $5 \mathrm{~kW}$ [18]. However, according to Rojanamon et al. [17], small hydropower projects vary from 2.5-25 MW of power generation. They further stated the most common value as $10 \mathrm{MW}$ according to Paish [5] and Demirmas [19].

Many of the countries have already developed large 
and medium hydropower projects and now they are eyeing on the small scale hydropower projects [20-23]. Scotland is one of the countries which targets $100 \%$ power supply from renewable resources by 2020 . They have already established $1.5 \mathrm{GW}$ of hydropower and still has the potential of another $500 \mathrm{MW}$. However, this $500 \mathrm{MW}$ is largely from small and mini hydropower projects [22].

Sri Lanka benefits around 20\% energy demand from hydropower. The Sri Lankan authorities have identified the last couple of major and medium hydropower stations and the government is working towards them. However, energy authorities look for mini and micro level hydropower stations heavily due to several reasons including environmental aspects [24-26]. Nevertheless, some countries like China and Brazil are still identifying the locations for massive hydropower projects due to their energy demand (examples: Lianghekou Dam $=3,000 \mathrm{MW}$, Shuangjiangkou Dam $=2,000 \mathrm{MW}$, Baihetan Dam $=$ 1,000 MW in China and Chacorão Dam = 3,336 MW, Jatobá Hydroelectric Power Plant = 2,338 MW, Belo Monte Dam = 11,233 MW in Brazil).

Small and mini hydropower stations have many advantages as well as some disadvantages against the massive hydropower stations. Most of the advantages are along the lines of environmental concerns. Usually, the small hydropower plants are run-of-the-river type hydropower stations. Therefore, there is no reservoir to store the water. Unlike the massive reservoirs, therefore, the damage to the biodiversity in the natural environment in run-of-the-river type hydropower station is minimum [27-28]. Moreover, the emission of greenhouse gases compared to massive hydropower plants is very small [29]. In addition, sedimentation is a significant issue for most of the massive reservoirs [30]. However, run-of-the-river type hydropower stations reduce that concern by usually having sedimentation tank [31]. Even though they are not listed here, there are several disadvantages in small hydropower projects [32-33].
These advantages and disadvantages are discussed locally (on the relevant place of construction) before a hydropower plant is constructed. However, there is minimum attention to the plants after construction, at least in the developing world. In Sri Lanka, the same scenario is practiced. No one really observes scientifically on the developed run-of-the-river type hydropower stations as far as they generate power. However, it is highly important to identify the socio environmental issues developed due to the construction of these hydropower stations because they would be the lessons learnt for the future projects. In addition, the authorities can improve the situation of the surrounding if there are any threatened problems due to the hydropower station. Highlighting this gap in Sri Lanka, we conducted research to identify the environmental and social impacts of a run-of-the-river type hydropower plant (named Denawaka Ganga mini hydropower station) in Sri Lanka.

\section{Regulation Degree (RD) and Environmental Impact Value (EIV)}

There are several techniques to quantify the environmental damage from a mini hydropower plant. Regulation degree and environmental impact value are two different ways of presenting the damage. Regulation degree is a measurement to calculate the impact caused by the change of hydrological regime characteristics which considered an impact to the surrounding environment in a physical manner [34]. Many researchers have used this to quantify the environmental damage due to newly developed flow structures as well as the climate change [35-39]. This can be presented in Eq. (1):

$$
R D=\frac{V_{\text {stored }}}{V_{\text {flow }}} \times 100 \%
$$

where, $R D, V_{\text {stored }}$ and $V_{\text {flow }}$ are regulation degree and the total water volume that can be stored and annual flow volume, respectively. Based on this $R D$ value, the flow regulation's impact on the stream can be classified. Table 1 table gives the classifications. 
Table 1 Classification of the environmental impact based on regulation degree [34].

\begin{tabular}{lll}
\hline Status & Class & Regulation degree \\
\hline High & 1 & 0 \\
Good & 2 & 09.99 \\
Moderate & 3 & $1,019.99$ \\
Unsatisfactory & 4 & $2,049.99$ \\
Poor & 5 & 50,100 \\
\hline
\end{tabular}

The total impact caused to the environment can be calculated using environment impact value (EIV). The summation of the impact values gives an overview idea on whether the power plant is a threat or an advantage to the country. The index was not only used to hydropower plants but also many other environmental concerned activities [40-44]. Even though there are various ways of expressing the index in the literature, we have used the mathematical explanation as given in Eq. (2):

$$
E I V=\sum_{i=1}^{n}\left(V_{i} \times W_{i}\right)
$$

where, $V_{i}$ is the relative change of environmental quality parameter, $W_{i}$ is the relative importance or weightage of the parameters and $n$ is the total number of parameters.

\section{Study Area}

Sri Lanka is blessed with water resources. Even though the country is divided into three major climatic zones (wet zone, intermediate zone and dry zone), the island receives a rainfall of 750-5,000 mm per annum. There are many mini hydropower (run-of-the-river type) plants in Sri Lanka. The story of mini hydropower goes to the British ruling time. Tea plantations in mountainous regions installed small hydropower plants to supply the electricity need of the factory [45]. However, many of them are given up now as they receive the national grid electricity as the energy source. Nevertheless, the governments of Sri Lanka have recently encouraged the private sector to even build new mini hydropower stations as a solution to the energy demand in the rapidly developing country.

Denawaka Ganga mini hydropower station is one of the run-of-the-river type hydropower stations owned by the private sector. It is in Ratnapura district. Ratnapura district is in the wet zone of the country and receives majority of the rainfall during the south west monsoon from May to September of the year [46]. In addition, Rathnapura is treated as a frequently flooding district of the country due to the intensity rainfall [47-49]. The Denawaka Ganga hydropower plant receives runoff water from $172.58 \mathrm{~km}^{2}$ catchment.

Fig. 1 shows the catchment area of the Denawaka Ganga hydropower plant. The catchment area is basically a natural forest area with few suburbs. Due to

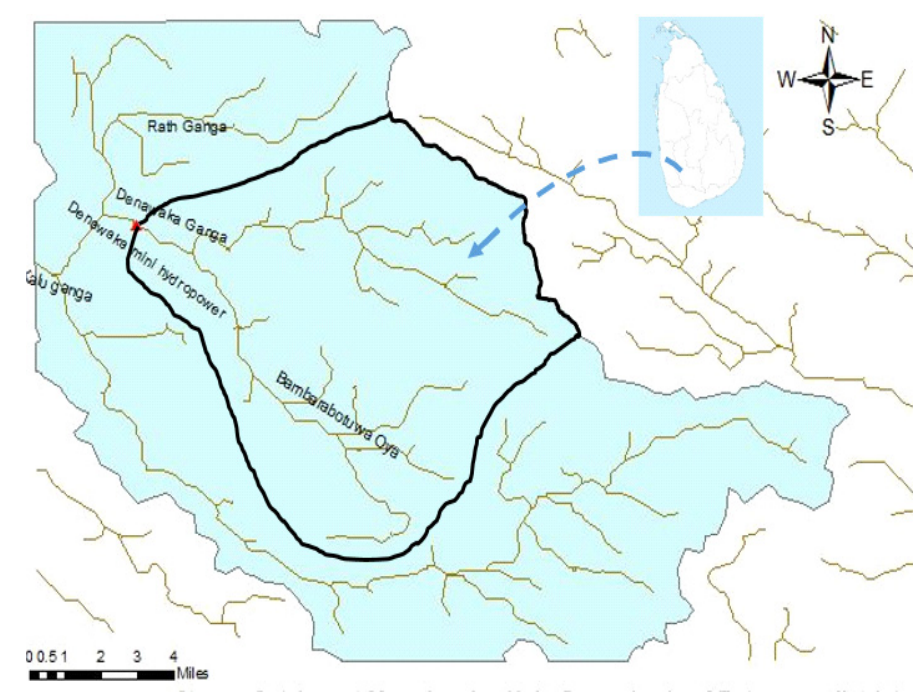

Fig. 1 Denawaka Ganga catchment. 
Fig. 2 Intake weir during a dry day.
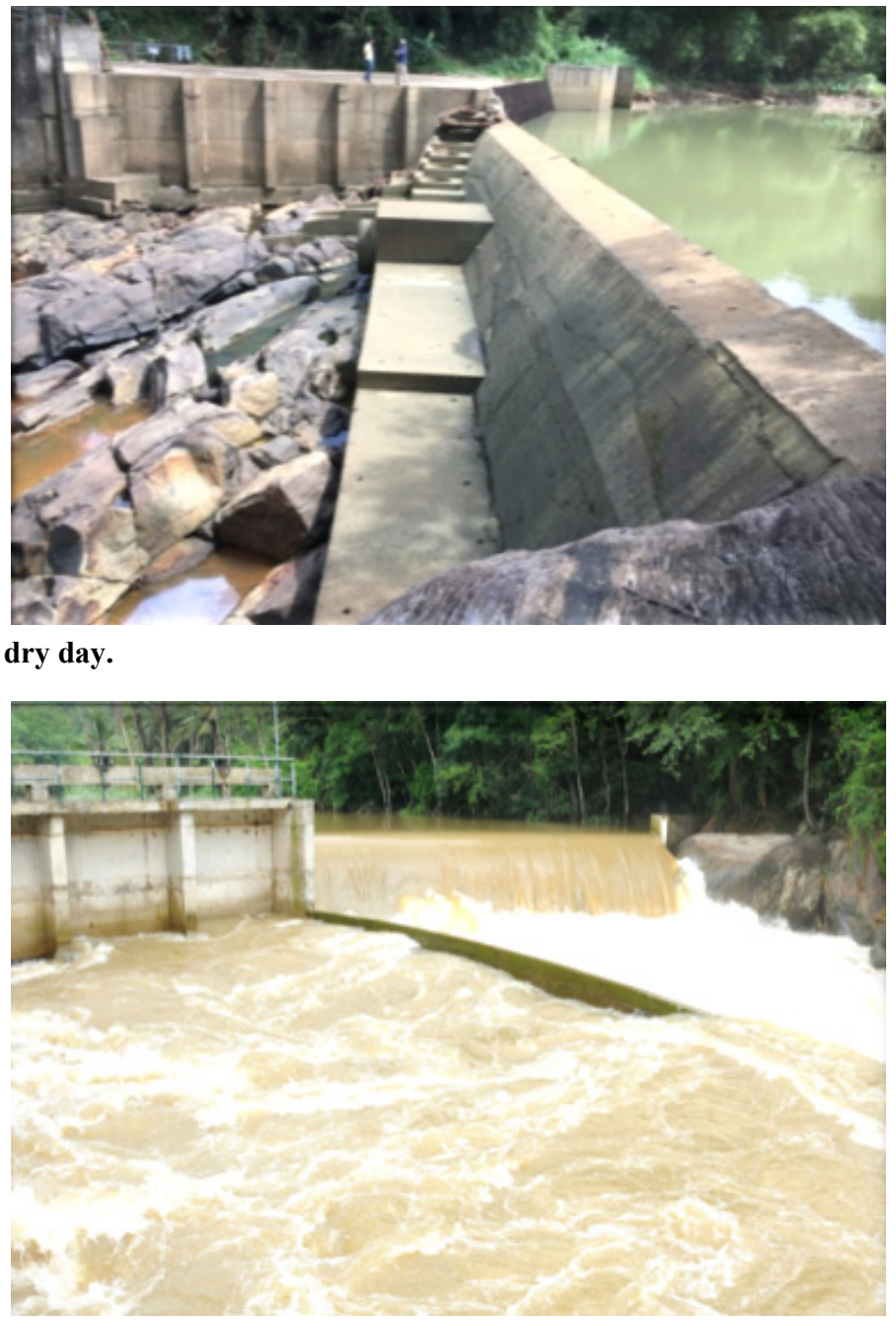

Fig. 3 Intake weir during a wet day.

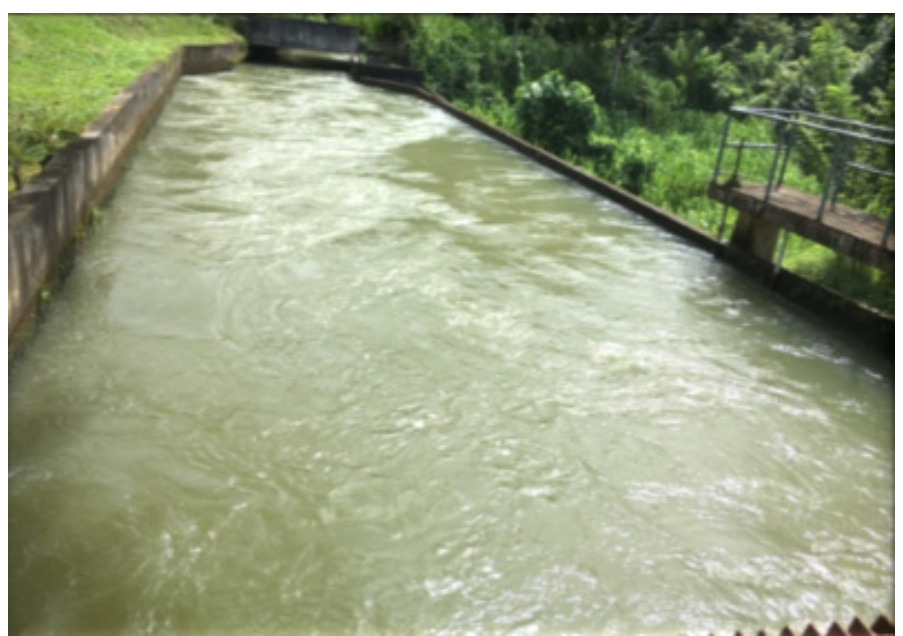

Fig. 4 Head raised canal.

the unpopulated catchment area, the water quality has ensured a better quality. Figs. 2 and 3 show the intake weir during the dry and wet weather periods, respectively. The head raised canal just above the forebay tank is shown in Fig. 4.

The project development was proposed in 2002 with 
a build capacity of $4.9 \mathrm{MW}$. However, after the government clearances, the project construction work started in 2009 with an updated capacity of 7.2 MW. The total investment was 905 million Rupees $(\approx 8$ million US\$ in 2009). Since 2013 it started to strengthen the national electricity grid by supplying electricity. The power plant consists of four horizontal Francis hydro turbines which are connected to four electricity generators.

\section{Approach}

Several field visits were arranged to the mini hydropower area and the surroundings during the time from May 2017 to October 2017. These included visiting the power plant, water intake weir and the village around the power plant. We were able to obtain the technical details of the power plant and the intake structures from the authorities employed at the power plant. In addition, we were able to obtain all technical specifications including the design consideration and the economics of the power generation. The digital maps of the area were bought from the survey department of Sri Lanka. These digital maps were used to draw the catchment area of Denawaka mini hydropower plant which was presented in Fig. 1.

The observations drafted from our field trips were used to calculate the EIV for the Denawaka Ganga mini hydropower plant. In addition, the National Red List published by the Central Environmental Authority, Sri Lanka, was referenced and to find out the available flora and fauna in the area [50]. The authors do not have subject specific knowledge to identify the whole list of flora and fauna; however, they have witnessed some of these when they are having the field trips. However, it is highly recommended to conduct a biodiversity analysis to identify the potential threats of the mini hydropower station on the flora and fauna.

In addition, we have discussed with the villages on the pros and cons of the mini hydropower station on their daily life. A questionnaire was carried out and identified some important feelings of the surrounding villages.

\section{Results and Discussion}

Hydrological regime analysis was carried out with reference to the variation characteristics given in Bergkamp et al. [51]. The followings are the findings:

- The average water flow of the mini hydropower plant is $11 \mathrm{~m}^{3} / \mathrm{s}$. This was maintained to a stabilized value;

- The Denawaka Ganga's water flow has almost been fully transmitted to the mini hydro power plant through the headrace. Hence there is no variation of the alternation;

- Heavy seasonal rainfalls can be witnessed in the area as it is in the wet zone of the Sri Lanka;

- The river has shorten flood peaks as well as shorten low flows;

- Rapid changes in the river can be observed in a shorter time as the river is prolonged to floods.

Flow magnitude, duration of flow, flow frequency, flood timing and the rate of change were identified as the fundamental characteristics influencing the physical and biological processes in a river [52]. Based on these fundamental characteristics and our above stated findings for Denawaka Ganga, Table 2 can be presented for the flow regime characteristics of the Denawaka Ganga.

According to Table 2, it can be clearly seen the hydrological regime characteristics caused due to the climate conditions. Therefore, a climatological analysis is recommended to identify the future trends of the rainfall to the catchment and then, to forecast the future flow conditions.

The regulation degree was calculated to the mini hydropower plant. There is no reservoir to the mini hydropower station and the weir was used to divert the water to the head raised canal. However, the upstream of the stream was pounded due to this weir. Therefore, a small reservoir is automatically created upstream to the weir. The average flow to the mini hydropower plant is $11 \mathrm{~m}^{3} / \mathrm{s}$. Therefore, $V_{\text {flow }}$ (annual flow volume) 
Table 2 Resulting hydrological regime characteristics.

\begin{tabular}{|l|l|l|}
\hline Flow characteristic & Alternation & Ecosystem response \\
\hline Flow magnitude & Stabilized flow & $\begin{array}{l}\text { Can contribute to failed establishment of riparian species and invasion of exotic } \\
\text { species. There will be a dominance of competitive species and loss of poor } \\
\text { competitors. }\end{array}$ \\
\hline Flow frequency & No variation & $\begin{array}{l}\text { No potential damage to the surrounding environment such as soil erosion or } \\
\text { biodiversity threats. }\end{array}$ \\
\hline Flood timing & $\begin{array}{l}\text { Loss/change of seasonal } \\
\text { flow variables }\end{array}$ & $\begin{array}{l}\text { Disturbed life cycles that will lead to reduced growth rate and changed succession } \\
\text { patterns. There will also be a reduced habitat availability. }\end{array}$ \\
\hline Flow duration & Shortened low flows & Increases the availability of aquatic habitats. \\
\cline { 2 - 3 } Rhortened flood peaks & Encroachment of land organisms into the riverbed. \\
\hline Rate of change of flow & $\begin{array}{l}\text { Rapid changes in river } \\
\text { stages }\end{array}$ & $\begin{array}{l}\text { Loss of riparian zone and its vegetation. Failed establishment of riparian } \\
\text { organisms because of wash out and stranding of organisms. }\end{array}$ \\
\hline
\end{tabular}

is $346 \mathrm{MCM} /$ year $(\mathrm{MCM}=$ million cubic meters). Compared to this $V_{\text {flow }}$ value, the storage above the weir is negligible. Therefore, the $R D$ value should be less than 10 and the water system can be classified to Class 1. Therefore, Denawaka Ganga mini hydropower plant does not cause potential adverse effect to the environment in the sense of hydrological regime.

However, the sediment flow in original river in the stretch of intake weir to mini hydropower plant (roughly $2 \mathrm{~km}$ ) is significantly blocked due to the head raised canal. The flow in that stretch is very low and therefore, the sediment flow is negligible. This makes adverse environmental effect on the surrounding and the aquatic life. However, sediment trapped in the screens of the head raised canal is released back to the downstream river. This helps to regain the nutrients flow from upstream to downstream.

Water quality tests were not carried out in this research. We believed the mini hydropower plant does not significantly involve in changing the water quality. This assumption was made as the Denawaka Ganga mini hydropower station is a non-reservoir type hydropower plant. Had it been incorporated with a reservoir, the water quality may be affected due to hydraulic retention time. However, there may be some oil and grease contamination due to the operation of roto-dynamic machines. Therefore, it is advisable to conduct some water quality analysis for oil and grease for the water release from the turbines.

However, the environmental impact value (EIV) was calculated for the Denawaka Ganga mini hydropower plant. As it was stated earlier, EIV is one of the methods which can be used to indicate the potential impact caused to the environment. Table 3 gives the different weightages used in the three subsections (physical, biological and social environments). Furthermore, it shows the calculations for $E I V$.

Our field visit observations and discussions with the villages were helped in completing the $E I V$ calculations. According to the summation of positive and negative impacts, Denawaka Ganga mini hydro power plant has reached to a value of -25 . Hence by comparing the weight of positive impacts and the negative impacts, it can be concluded that there is a potential threat which can be caused by mini hydro power plants to the surrounding environment. The EIV results are presented in Fig. 5 for better understanding of impact on subsections.

Fig. 5 clearly presents the negative impacts of the mini hydropower plant for the physical and biological environment. The adverse impact on biological environment is quite significant. Therefore, as it was stated in the earlier section of the paper, a detailed biodiversity analysis is recommended. However, the mini hydropower plant has made a positive impact to the physical environment and social environment. Re-forestation and recycling of waste to generate compost were two of the important positive impacts from the mini hydropower plant.

The positive impacts of social environment were found from the discussions among the villages. Construction of several concrete roads (previously 
these roads were either muddy roads without proper cover), construction of causeway across Denawaka Ganga, renovation of religious centers and community halls in the area were few of the other identified positive social impacts of the Devaka Ganga mini hydropower project.

Table 3 EIV calculations.

\begin{tabular}{|c|c|c|c|}
\hline Impact & $V_{i}$ & $W_{i}$ & $V_{i} W_{i}$ \\
\hline \multicolumn{4}{|l|}{ Physical environment } \\
\hline Micro-climate and air quality & 0 & 3 & 0 \\
\hline Change of flow characteristics & 1 & 3 & $3(-\mathrm{ve})$ \\
\hline Topography and land use & 2 & 2 & $4(-\mathrm{ve})$ \\
\hline Surface erosion & 1 & 2 & $2(-\mathrm{ve})$ \\
\hline Disposal of excavated material & 1 & 2 & $2(-\mathrm{ve})$ \\
\hline Hydrology and sedimentations & 0 & 2 & 0 \\
\hline Water quality/pollution & 0 & 4 & 0 \\
\hline Solid waste & 0 & 3 & 0 \\
\hline Re-forestation & 2 & 3 & $6(+\mathrm{ve})$ \\
\hline Composting and recycling & 2 & 2 & $4(+\mathrm{ve})$ \\
\hline Noise and vibration & 2 & 2 & $4(-\mathrm{ve})$ \\
\hline \multicolumn{4}{|l|}{ Biological environment } \\
\hline Loss of forest cover & 1 & 3 & $3(-\mathrm{ve})$ \\
\hline Increase in felling trees & 1 & 2 & $2(-\mathrm{ve})$ \\
\hline Exploitation of non-timber forest products & 2 & 2 & $4(-\mathrm{ve})$ \\
\hline Impact on biodiversity & 3 & 3 & $9(-\mathrm{ve})$ \\
\hline Impact on rare endangered and threatened species & 3 & 3 & $9(-\mathrm{ve})$ \\
\hline Impact on fish migration & 1 & 2 & $2(-\mathrm{ve})$ \\
\hline Effect on riparian habitat & 1 & 2 & $2(-\mathrm{ve})$ \\
\hline Downstream effect & 0 & 1 & 0 \\
\hline \multicolumn{4}{|l|}{ Social environment } \\
\hline Impacts in agricultural land & 0 & 2 & 0 \\
\hline Women and child labour & 0 & 2 & 0 \\
\hline Culture and religion & 1 & 1 & $1(-\mathrm{ve})$ \\
\hline Public health & 1 & 3 & $3(-\mathrm{ve})$ \\
\hline Occupational health and safety & 0 & 4 & 0 \\
\hline Law and order & 1 & 3 & $3(-\mathrm{ve})$ \\
\hline Impact on local life style & 1 & 1 & $1(-\mathrm{ve})$ \\
\hline Increase pressure on local services & 0 & 1 & 0 \\
\hline Increased local employment & 3 & 2 & $6(+\mathrm{ve})$ \\
\hline Increase in local trade & 3 & 2 & $6(+\mathrm{ve})$ \\
\hline Improvement in road condition & 3 & 1 & $3(+\mathrm{ve})$ \\
\hline Rural electrification & 4 & 2 & $8(+\mathrm{ve})$ \\
\hline Industrialization & 2 & 2 & $4(+\mathrm{ve})$ \\
\hline Promotion in eco-tourism & 1 & 2 & $2(+\mathrm{ve})$ \\
\hline
\end{tabular}

Note: +ve: positive; -ve: negative. 


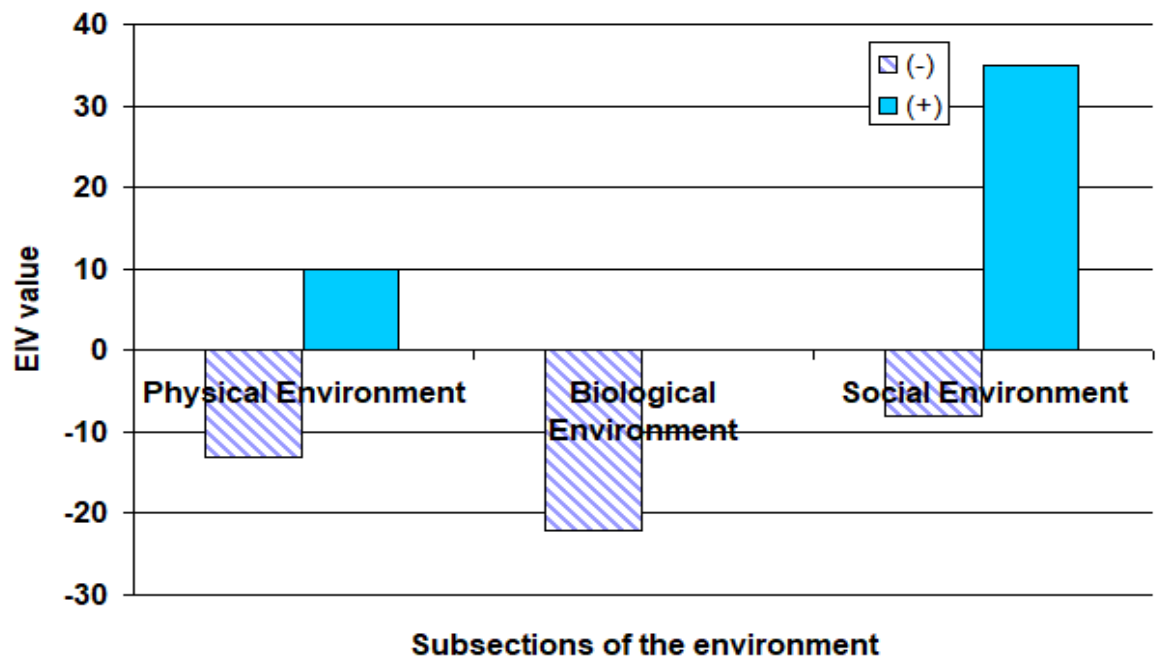

Fig. 5 EIVs for subsections of the environment.

\section{Conclusions}

A well functioned mini hydropower plant in Sri Lanka was selected as a case study to present the potential social and environmental impacts from a mini hydropower plant. The study shows some critical concerns on the environment; however, the positive gain to the society is significant. Therefore, Denawaka Ganga mini hydropower plant is an asset to the country. However, it is proposed to conduct future research to identify the rectification methods to bring the negative impacts to a much lower level. This includes conducting a water quality analysis and a biodiversity analysis. In addition, it is recommended to use $E I V$ and $R D$ values to assess the other mini-hydropower plants in the country. Based on the assessment, authorities can re-think on continuation of mini-hydropower plants if they score significant negative $E I V$ scores. At the same time, if the assessed mini-hydropower plant has positive scores or insignificant negative values in $E I V$, they should be rewarded.

\section{Acknowledgments}

The authors would like to acknowledge the support received from authorities of Country Energy (Pvt) Ltd, Sri Lanka and the respondents of our survey.

\section{References}

[1] Kjærland, F. 2007. "A Real Option Analysis of Investments in Hydropower-The Case of Norway." Energy Policy 35 (11): 5901-8.

[2] Chang, X., Liu, X., and Zhou, W. 2010. "Hydropower in China at Present and Its Further Development." Energy 35 (11): 4400-6.

[3] Kumar, A., Kumar, K., Kaushik, N., Sharma, S., and Mishra, S. 2010. "Renewable Energy in India: Current Status and Future Potentials." Renewable and Sustainable Energy Reviews 14 (8): 2434-42.

[4] Evans, A., Strezov, V., and Evans, T. 2009. "Assessment of Sustainability Indicators for Renewable Energy Technologies." Renewable and Sustainable Energy Reviews 13 (5): 1082-8.

[5] Paish, O. 2002. "Small Hydro Power: Technology and Current Status." Renewable and Sustainable Energy Reviews 6 (6): 537-56.

[6] Sims, R., Rogner, H., and Gregory, K. 2003. "Carbon Emission and Mitigation Cost Comparisons between Fossil Fuel, Nuclear and Renewable Energy Resources for Electricity Generation.” Energy Policy 31 (13): 1315-26.

[7] Jager, H., and Smith, B. 2008. "Sustainable Reservoir Operation: Can We Generate Hydropower and Preserve Ecosystem Values?.” River Research and Applications 24 (3): 340-52.

[8] Rahman Mohamed, A., and Lee, K. 2006. "Energy for Sustainable Development in Malaysia: Energy Policy and Alternative Energy.” Energy Policy 34 (15): 2388-97.

[9] Yuksel, I. 2010. "As a Renewable Energy Hydropower for Sustainable Development in Turkey." Renewable and Sustainable Energy Reviews 14 (9): 3213-9. 
[10] Yüksel, I. 2010. "Hydropower for Sustainable Water and Energy Development." Renewable and Sustainable Energy Reviews 14 (1): 462-9.

[11] Bayazıt, Y., Bakış, R., and Koç, C. 2017. "An Investigation of Small Scale Hydropower Plants Using the Geographic Information System." Renewable and Sustainable Energy Reviews 67: 289-94.

[12] Bousquet, C., Samora, I., Manso, P., Rossi, L., Heller, P., and Schleiss, A. 2017. "Assessment of Hydropower Potential in Wastewater Systems and Application to Switzerland." Renewable Energy 113: 64-73.

[13] Hermoso, V. 2017. "Freshwater Ecosystems Could Become the Biggest Losers of the Paris Agreement." Global Change Biology 23 (9): 3433-6.

[14] Hoes, O., Meijer, L., Van der Ent, R., and Van de Giesen, N. 2017. "Systematic High-Resolution Assessment of Global Hydropower Potential." PLOS ONE 12 (2): 1-10.

[15] Manzano-Agugliaro, F., Taher, M., Zapata-Sierra, A., Juaidi, A., and Montoya, F. 2017. "An Overview of Research and Energy Evolution for Small Hydropower in Europe." Renewable and Sustainable Energy Reviews 75: 476-89.

[16] Nastase, G., Şerban, A., Năstase, A., and Iordan, N. 2017. "Hydropower Development in Romania. A Review from Its Beginnings to the Present." Renewable and Sustainable Energy Reviews 80: 297-312.

[17] Rojanamon, P., Chaisomphob, T., and Bureekul, T. 2009. "Application of Geographical Information System to Site Selection of Small Run-of-River Hydropower Project by Considering Engineering/Economic/Environmental Criteria and Social Impact." Renewable and Sustainable Energy Reviews 13 (9): 2336-48.

[18] Williams, A., and Porter, S. 2006. "Comparison of Hydropower Options for Developing Countries with Regard to the Environmental, Social and Economic Aspects." In Proceedings of the International Conference on Renewable Energy for Developing Countries, 1-17.

[19] Demirbas, A. 2005. "Potential Applications of Renewable Energy Sources, Biomass Combustion Problems in Boiler Power Systems and Combustion Related Environmental Issues." Progress in Energy and Combustion Science 31 (2): 171-92. doi:10.1016/j.pecs.2005.02.002.

[20] Bracken, L., Bulkeley, H., and Maynard, C. 2014. "Micro-hydro Power in the UK: The Role of Communities in an Emerging Energy Resource." Energy Policy 68: 92-101.

[21] Morales, S., Álvarez, C., Acevedo, C., Diaz, C., Rodriguez, M., and Pacheco, L. 2015. "An Overview of Small Hydropower Plants in Colombia: Status, Potential, Barriers and Perspectives." Renewable and Sustainable Energy Reviews 50: 1650-7.

[22] Sample, J., Duncan, N., Ferguson, M., and Cooksley, S.
2015. "Scotland's Hydropower: Current Capacity, Future Potential and the Possible Impacts of Climate Change." Renewable and Sustainable Energy Reviews 52: 111-22.

[23] Wagner, B., Hauer, C., Schoder, A., and Habersack, H. 2015. "A Review of Hydropower in Austria: Past, Present and Future Development." Renewable and Sustainable Energy Reviews 50: 304-14.

[24] Eriyagama, N., Smakhtin, V., and Jinapala, K. 2016. "The Sri Lanka Environmental Flow Calculator: A Science-Based Tool to Support Sustainable National Water Management." Water Policy 18 (2): 480-92.

[25] Fernando, S. 2002. "An Assessment of the Small Hydro Potential in Sri Lanka." Energy for Sustainable Development 6 (1): 95-8.

[26] Morimoto, R., and Munasinghe, M. 2005. "Small Hydropower Projects and Sustainable Energy Development in Sri Lanka." International Journal of Global Energy Issues 24 (1/2): 3.

[27] Anderson, D., Moggridge, H., Warren, P., and Shucksmith, J. 2014. "The Impacts of 'Run-of-River' Hydropower on the Physical and Ecological Condition of Rivers." Water and Environment Journal 29 (2): 268-76.

[28] Winemiller, K., McIntyre, P., Castello, L., Fluet-Chouinard, E., Giarrizzo, T., Nam, S., Baird, I., Darwall, W., Lujan, N., Harrison, I., Stiassny, M., Silvano, R., Fitzgerald, D., Pelicice, F., Agostinho, A., Gomes, L., Albert, J., Baran, E., Petrere, M., Zarfl, C., Mulligan, M., Sullivan, J., Arantes, C., Sousa, L., Koning, A., Hoeinghaus, D., Sabaj, M., Lundberg, J., Armbruster, J., Thieme, M., Petry, P., Zuanon, J., Vilara, G., Snoeks, J., Ou, C., Rainboth, W., Pavanelli, C., Akama, A., Soesbergen, A., and Saenz, L. 2016. "Balancing Hydropower and Biodiversity in the Amazon, Congo, and Mekong." Science 351 (62-69): 128-9.

[29] Yah, N., Oumer, A., and Idris, M. 2017. "Small Scale Hydro-Power as a Source of Renewable Energy in Malaysia: A Review." Renewable and Sustainable Energy Reviews 72: 228-39.

[30] Adam, N., Erpicum, S., Archambeau, P., Pirotton, M., and Dewals, B. 2014. "Stochastic Modelling of Reservoir Sedimentation in a Semi-arid Watershed." Water Resources Management 29 (3): 785-800.

[31] Weerakoon, S. B., and Rathnayake, U. S. 2007. "Effect of the Entrance Zone on the Trapping Efficiency of Desilting Tanks in Run-of-River Hydropower Plants." In International Conference on Small Hydropower-Hydro Sri Lanka, 22-4.

[32] Abbasi, T., and Abbasi, S. 2011. "Small Hydro and the Environmental Implications of Its Extensive Utilization." Renewable and Sustainable Energy Reviews 15 (4): 2134-43. 
[33] Gracey, E., and Verones, F. 2016. "Impacts from hydropower production on biodiversity in an LCA framework-review and recommendations." The International Journal of Life Cycle Assessment 21(3): 412-28.

[34] Steinmetz, M., and Sundqvist, N. 2014. "Environmental Impacts of Small Hydropower Plants-A Case Study of Borås Energi och Miljö's Hydropower Plants.” Master of Science thesis, Chalmers University of Technology.

[35] Arheimer, B., Donnelly, C., and Lindström, G. 2017. "Regulation of Snow-Fed Rivers Affects Flow Regimes More than Climate Change." Nature Communications 8 (1): $1-9$

[36] Gao, G., Li, T., Liu, Z., and Li, X. 2013. "Advances and Prospects of Reservoir Sedimentation Problem on Sediment-Laden River." Applied Mechanics and Materials 405-408: 2104-14.

[37] Tongal, H., and Berndtsson, R. 2016. "Impact of Complexity on Daily and Multi-step Forecasting of Streamflow with Chaotic, Stochastic, and Black-Box Models." Stochastic Environmental Research and Risk Assessment 31 (3): 661-82.

[38] Zhang, R., Chen, X., Zhang, Z., and Shi, P. 2014. "Evolution of Hydrological Drought under the Regulation of Two Reservoirs in the Headwater Basin of the Huaihe River, China." Stochastic Environmental Research and Risk Assessment 29 (2): 487-99.

[39] Zhangzhong, L., Yang, P., Ren, S., Liu, Y., and Li, Y. 2015. "Flow Characteristics and Pressure-Compensating Mechanism of Non-pressure-Compensating Drip Irrigation Emitters." Irrigation and Drainage 64 (5): 637-46.

[40] Coelho, A., and De Brito, J. 2012. "Influence of Construction and Demolition Waste Management on the Environmental Impact of Buildings." Waste Management 32 (3): 532-41.

[41] Huisman, J., Boks, C., and Stevels, A. 2003. "Quotes for Environmentally Weighted Recyclability (QWERTY): Concept of Describing Product Recyclability in Terms of Environmental Value." International Journal of Production Research 41 (16): 3649-65.

[42] Lu, L., Wernick, I., Hsiao, T., Yu, Y., Yang, Y., and Ma, H.
2006. "Balancing the Life Cycle Impacts of Notebook Computers: Taiwan's Experience." Resources Conservation and Recycling 48 (1): 13-25.

[43] Rydh, C. 1999. "Environmental Assessment of Vanadium Redox and Lead-Acid Batteries for Stationary Energy Storage." Journal of Power Sources 80 (1-2): 21-9.

[44] Safont, E., Vegas-Vilarrúbia, T., and Rull, V. 2012. Use of Environmental Impact Assessment (EIA) Tools to Set Priorities and Optimize Strategies in Biodiversity Conservation.” Biological Conservation 149 (1): 113-21.

[45] Wijayatunga, P. 2014. "Regulation for Renewable Energy Development: Lessons from Sri Lanka Experience." Renewable Energy 61: 29-32.

[46] Punyawardena, B., and Cherry, N. 1999. "Assessment of the Predictability of Seasonal Rainfall in Ratnapura Using the Southern Oscillation and Its Two Extremes." Journal of the National Science Foundation of Sri Lanka 27 (3): 187-95.

[47] Churchill, R., and Hutchinson, D. 1984. "Flood Hazard in Ratnapura, Sri Lanka: Individual Attitudes vs. Collective Action." Geoforum 15 (4): 517-24.

[48] Eriyagama, N., Thilakarathne, M., Tharuka, P., Munaweera, T., Muthuwatta, L., Smakhtin, V., Premachandra, W., Pindeniya, D., Wijayarathne, N., and Udamulla, L. 2017. "Actual and Perceived Causes of Flood Risk: Climate versus Anthropogenic Effects in a Wet Zone Catchment in Sri Lanka."Water International 42 (7): 874-92.

[49] Nandalal, K. 2009. "Use of a Hydrodynamic Model to Forecast Floods of Kalu River in Sri Lanka.” Journal of Flood Risk Management 2 (3): 151-8.

[50] MOE 2012. "The National Red List 2012 of Sri Lanka; Conservation Status of the Fauna and Flora."Ministry of Environment, Colombo, Sri Lanka. 7: 476

[51] Bergkamp, G., McCartney, M., Dugan, P., McNeely, J., Acreman, M. 2000. "Dams, Ecosystem Functions and Environmental Restoration: Thematic Review II." 1 World Commission on Dams, Cape Town, South Africa

[52] Renafalt, B., Jansson, R., and Nilsson, C. 2010. "Effects of Hydropower Generation and Opportunities for Environmental Flow Management in Swedish Riverine Ecosystems." Freshwater Biology 55 (1): 49-67. 